Annals of Warsaw University of Life Sciences - SGGW

Land Reclamation No 49 (1), 2017: 3-14

(Ann. Warsaw Univ. Life Sci. - SGGW, Land Reclam. 49 (1), 2017)

\title{
The grain size distribution of settled sediment within storage reservoir Otmuchów
}

\author{
ROBERT GŁOWSKI, ROBERT KASPEREK
}

Institute of Environmental Engineering, Wrocław University of Environmental and Life Sciences

\begin{abstract}
The grain size distribution of settled sediment within storage reservoir Otmuchów. The river Nysa Kłodzka is flowing through the flat-reduction Otmuchów. There are localized two storage reservoirs Otmuchów and Nysa. The first of these reservoirs have been constructed in the period 1928-1933 and the filling was completed in 1934. Reservoir Nysa was completed in 1971. Both reservoirs are located within walking distance of each other, creating since 1971 cascade. Reservoir Otmuchów is located above the Nysa reservoir what cause, that in the bowl of the Otmuchów reservoir, the significant part of transported by Nysa Kłodzka sediments is deposited. When established after the 1997 flood damming levels, summer and winter, the length of the reservoir Otmuchów is suitably from 4.5 to $5 \mathrm{~km}$. At the maximum impoundment level and a maximal capacity of 130.45 million $\mathrm{m}^{3}$ the reservoir length reach approx. $7 \mathrm{~km}$. From the analysis of the satellite image can be seen advancing silting of the reservoir Otmuchów especially in the estuary zone of the Nysa Kłodzka. Obtained archival data about changes of the sediment grain size distribution in the longitudinal reservoir profile cover only the region of the still capacity extending a distance of $3 \mathrm{~km}$ from the cross-section of the dam. In this zone the fine particles of the suspended load with characteristic diameters ranging from 0.030 to $0.088 \mathrm{~mm}$ were embedded. In 2010, the authors presented the results of preliminary analysis of the silting process of the reservoir Otmuchów. The authors pointed out that there is a lack of the data about the dimension of the particles embedded in the usable capacity and flood capacity reserve (above $3 \mathrm{~km}$ from the dam) causing visible on satellite photo silting. This pa-
\end{abstract}

per presents the results of the sediment grain size distribution in the usable capacity of the reservoir and in the estuary region of the Nysa Kłodzka located in flood capacity reserve, obtained from the sediment samples analysis. Obtained results allowed to supplement the image of the particle size distribution of the sediment being deposited in the reservoir Otmuchów longitudinal profile and an evaluation of the parameters of mobility rubble with fixed diameters.

Key words: reservoir silting, settlement, sediments

\section{INTRODUCTION}

Conducted on the reservoirs water management is related to securing specific water resources for water supply systems, agriculture, energy production, navigation etc. The function of water reservoirs is also protection against floods and the drought periods. Constructed reservoir should perform their functions for a long period of time calculated in years. One of many problems connected with the exploitation of the reservoir in long term is its silting. Construction of the dam in the natural river valley, cause the interruption of sediment transport. In the reservoir greater part of sediments transported by the river is trapped. Coarser sediments with diameters $(d)$ larger than 
$2 \mathrm{~mm}$ are deposited in the zone of the river estuary. Smaller sediment fractions with diameters below $2 \mathrm{~mm}$ can be transported through the whole reservoir and are deposited in the middle part of the reservoir and in direct neighborhood of the dam. Trapped sediments reduce reservoir capacity what is important for water management (Głowski et al. 2010). The intensity of the reservoir sedimentation depends on intensity and amount of sediment transport in flowing river. To ensure the proper functioning of the reservoir and the fulfillment of certain tasks of water management is needed to observe changes in its volume and spatial distribution of the various fractions of sediments. Maintenance of the constant reservoir capacity is associated with periodic removal of sediments. Knowledge about spatial grain size distribution in reservoir is important for the estimation of the conditions of sediment erosion, choosing the way how to remove them, how much of the sediments should be removed to restore the reservoir capacity. Sediment erosion conditions partly depends on their grain size composition. Erosion of coarser mineral sediments $(d$ $>0.5 \mathrm{~mm}$ ) without presence of cohesion have a different erosion behavior in comparison of sediments composed with small particles $(d<0.5 \mathrm{~mm})$ where the influence of cohesion occurs. The spatial sediment distribution in the reservoir and its properties decide how big volume of sediments can be removed. In the case of reservoir Otmuchów exist partial data about spatial grain size distribution in the longitudinal reservoir profile.

\section{SCIENTIFFIC AND RESEARCH BACKGROUND}

The development of new water reservoirs determine among other things the growing water needs of humanity and the need to protect people, their settlements from the ravages of floods. Due to the long investment cycle is still building new reservoirs, more and more attention is paid to maintaining adequate capacity of the existing reservoirs. The international organization CIGB ICOLD (CIGB ICOLD 2009) conducted in 2009 (using the Register of Dams ICOLD) the world's assessment of the current and projected state of reservoirs siltation and ecological impact of dams on morphological fluvial processes. According to this report (ICOLD 2009), based on the available data, rated level of the rate of silting of water reservoirs in Europe. It has been found that it is lower than the global average level of siltation. The estimated average annual value of the loss of capacity of the reservoirs in Poland, rated on the basis of data from 1980 , based on the available data for only 6 reservoirs (6 dams entered in the Register of Dams ICOLD), the average is $0.62 \%$ annually. For comparison, in Germany it amounts to $0.17 \%$ annually ( 8 tanks in the Register of Dams ICOLD), and in Spain $0.46 \%$ annually (21 reservoirs in the Register of Dams ICOLD). In view 
of the increasing need to maintain the capacity of the reservoirs, the assessment of the capacity loss should be conducted on the basis of current and realistic data on the rate of silting. This requirement can be met only through the introduction of regular testing and measurements of tank capacity. According to available on the Internet (www.naukowiec.org, 2016) data about the number the significant water reservoirs in Poland it is mentioned as many as 38 ( ICOLD data base 1980 only 6), the 9 tanks are reservoirs with a maximum capacity above 100 million $\mathrm{m}^{3}, 10$ tanks with capacities ranging from 50 to 100 million $\mathrm{m}^{3}$ and 19 tanks with capacities ranging from 10 to 50 million $\mathrm{m}^{3}$. The official website of the Institute of Meteorology and Water Management (www.pogodynka.pl), you can find data on 18 major reservoirs in Poland. Problem realistic assessment of the capacity of water reservoirs (even those of lesser importance) and the rate of its loss, forcing to the development of local reports about the state of water reservoirs, such as the Polish report prepared by IMGW in Warsaw in 2009-2010, as part of the European Union - Climate, Innovative National Cohesion Strategy - Task 8. It concerned the prevention of degradation of the Polish reservoirs (IMGW 2010). Another example is the British report prepared by Halcow Water commissioned by The Department of Environment Transport and the Regions (DETR 2001). These studies allow for a more accurate analysis of changes in reservoirs volume as a result of stopping by the reservoir of sediment (Michalec et al. 2009, Bąk and Dąbkowski 2013, Wicher-Dysarz and Dysarz 2014). Change of priorities in the management of capacity of the water reservoirs contribute over time to the intensification of silting and loss of capacity (Graf 1984). The example is the reservoir in Otmuchowie whose primary function until 1997, was to collect water for power Odra river in dry periods and electricity production. After the 1997 flood were changed rules of water management in this reservoir. Currently, its primary function is flood control. This change meant that for a considerable period of the year the tank operates under reduced water level, which means that the upper part of the reservoir (estuary) is exposed to increased siltation. In this upper zone, the vegetation development take place (reeds, shrubs, occasionally even the trees) which contributing to the intensification of siltation and sludge stabilization. The impact of pioneering vegetation on the reservoir siltation was described by Elliott (2000), Wicher-Dysarz and Dysarz (2006, 2014), Głowski and Parzonka (2007), De Andrade Cunha and Ferreira (2012). Research of De Andrade Cunhy and Ferreira (2012) were devoted mainly to assessment of adverse ecological changes in the pioneer vegetation composition that occur at the time of the construction of the Belo Monte dam, which will result in damming the Xingu river for hydro- 
power. The effect of the sediment particle stopping caused by vegetation is used in specially designed reservoirs, so-called entrance reservoirs (settler) or artificially created wetlands. In such embodiments, the area of the reservoir preovergrown vegetation, macrophyte, its task is to clear the incoming water from the sediments and improve its quality in the main tank (Pikul and Mokwa 2008, Górski 2009). In the case of older reservoirs, without the entrance reservoirs, the preliminary retention of sediments caused by the vegetation occuring in the upper part (estuary) of the reservoir, not only results in the gradual loss of its capacity but can cause further deterioration of hydrodynamic conditions of flow and sediment transport in the section of the river above the its mouth (Morris and Fun 1998, Przedwojski 1998).
LOCALIZATION

AND SPECIFICATION

OF RESERVOIR OTMUCHÓW

Reservoir Otmuchów have been localized in south-west part of Poland (Lower Silesia) in the region of depression Otmuchów, between cities Kamieniec Ząbkowicki and Nysa. Geologically the depression Otmuchów is $20-50 \mathrm{~m}$ deep indented channel, filled with tertiary deposits, covered on the lenght about $20 \mathrm{~km}$ and width $1-3 \mathrm{~km}$ with quatenary sediments. The water region Otmuchów have been created in the period 1928-1934 by the dam construction on Nysa Kłodzka river. The dam of the reservoir is located in $77.194 \mathrm{~km}$ on Nysa Kłodzka (Fig. 1). Reservoir Otmuchów is the oldest reservoir built on the Nysa Kłodzka. The functioning of the reservoir is complicated because, below Otmuchów

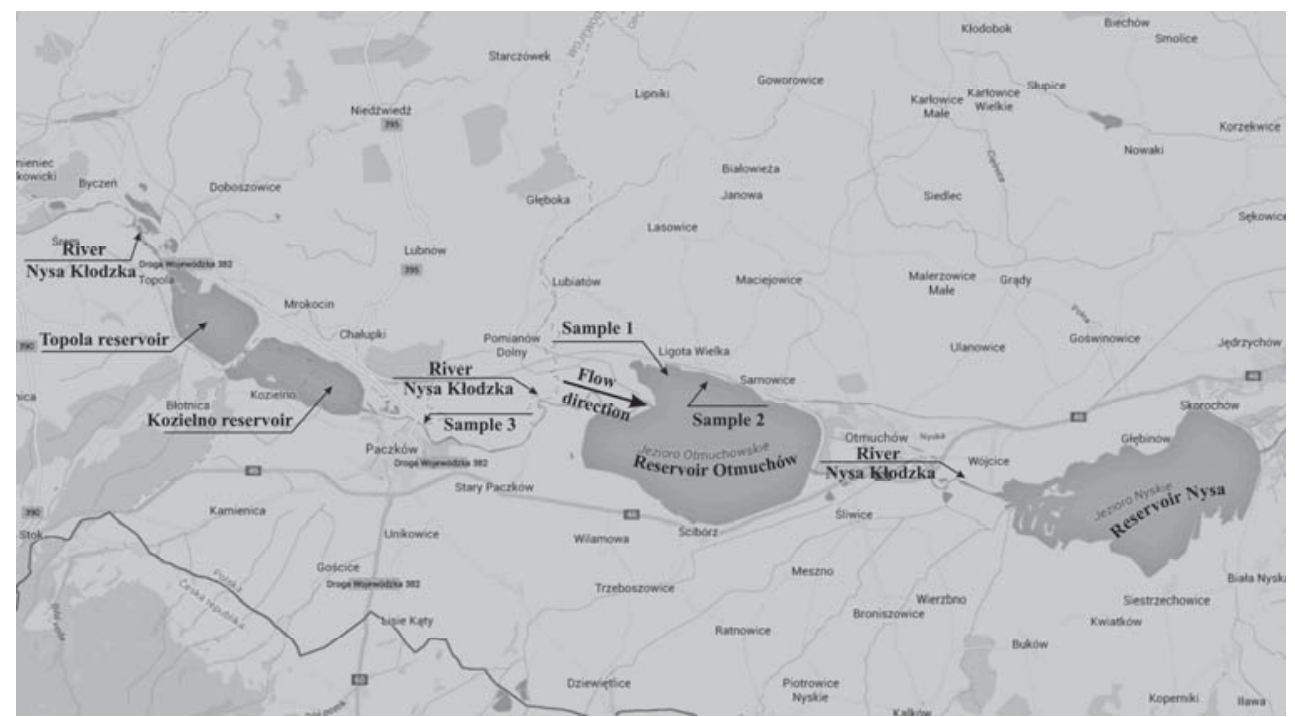

FIGURE 1. Localization of the reservoir Otmuchów 
in 1971 the reservoir Nysa $(\mathrm{km} \mathrm{62.95)}$ have been constructed. In turn, in period 1986-2002 also above the reservoir Otmuchów, two new reservoirs Topola ( $\mathrm{km}$ 97.7) and Kozielno ( $\mathrm{km}$ 93.4) have been constructed. From 2002 all these four reservoirs consist of cascade and modified the hydrological river regime (discharges, water levels, local hydraulic gradient, sediment transport conditions etc.) on the river lenght about $35 \mathrm{~km}$. Estimated mean hydraulic gradient value throughout the course of the Nysa Kłodzka is equal $I=4.41 \%$ (Kotusz et al. 2009). In upper $80-\mathrm{km}$ long part of the Nysa Kłodzka, having the mountain character, estimated value of the mean hydraulic gradient is greater and obtain value $I=9.5 \%$ (Kotusz et al. 2009). When established after the 1997 flood damming levels, summer and winter, the lenght of the reservoir Otmuchów is suitably from 4.5 to $5 \mathrm{~km}$. At the maximum impoundment level and a maximal capacity of 130.45 million $\mathrm{m}^{3}$ the reservoir length reach approx. $7 \mathrm{~km}$. From the analysis of the satellite image (Fig. 2) can be seen advancing silting of the reservoir Otmuchów especially in the estuary zone of the Nysa Kłodzka. Obtained archival data about changes of the sediment grain size distribution in the longitudinal reservoir profile cover only the region of the still capacity extending a distance of $3 \mathrm{~km}$ from the cross-section of the dam (Głowski et al. 2010). In this zone the fine particles of the suspended load with characteristic diameters ranging from 0.030 to $0.088 \mathrm{~mm}$ were embedded. There is a lack of the data about the dimension of the particles embeded in the usable

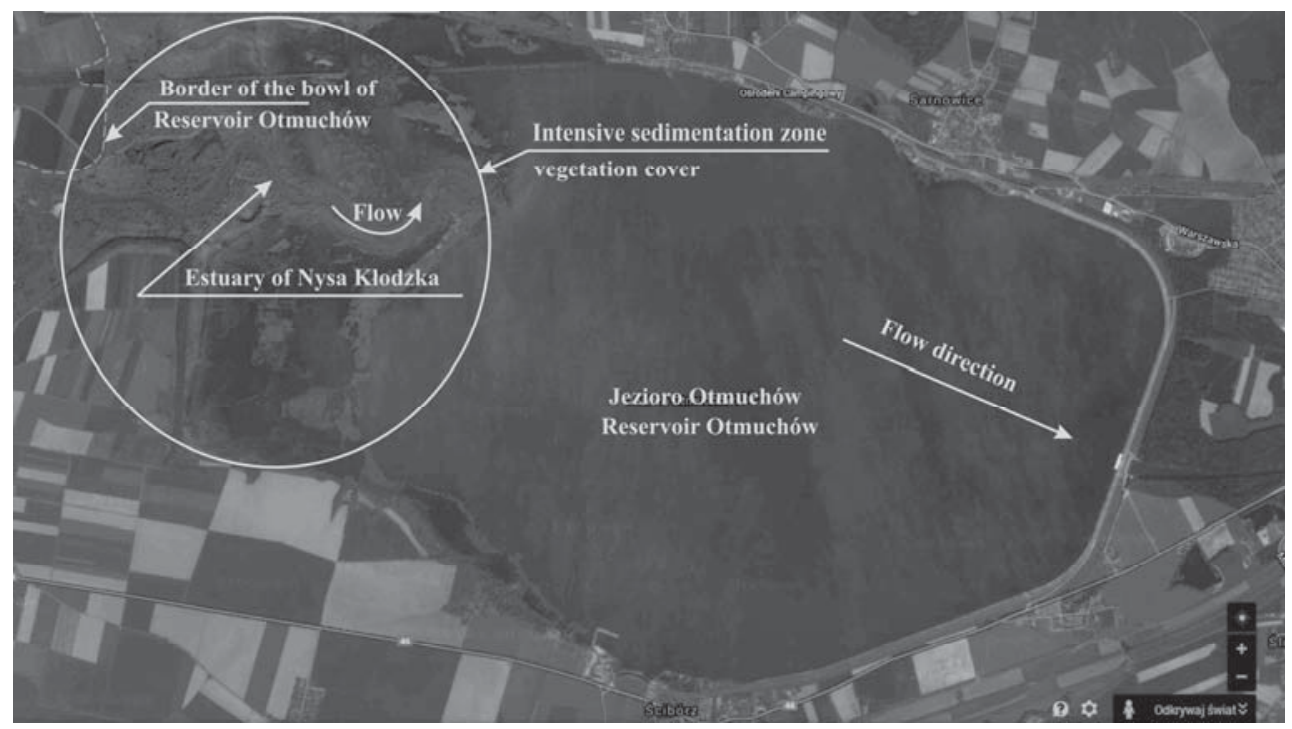

FIGURE 2. Satellite view of the reservoir Otmuchów. Photography after Google Maps (www.googlemaps.pl), modified by authors 
capacity and flood capacity reserve (above $3 \mathrm{~km}$ from the dam) causing visible on satellite photo silting (Fig. 2).

\section{MATERIAL AND METHODS}

For complete the data about particle size distribution in upper part of the reservoir Otmuchów in the June of 2014 (summer time), 3 sediment samples have been taken. First one (labeled Sample 1) have been taken about 4,800 $\mathrm{m}$ from the dam in Nysa Kłodzka estuary zone (flood capacity reserve). Characteristic of this zone is the presence of vegetation covering the embedded sediments. Second sample (Sample 2) have been acquired in a distance about $3,900 \mathrm{~m}$ from the dam (usable capacity). For the analysis of the difference in grain size distribution in these 2 samples the third (Sample 3) have been taken, $5.7 \mathrm{~km}$ above the Nysa
Kłodzka estuary. Sample 3 was taken from the mainstream zone of the riverbed. The analysis of the grain size distribution ware performed accordingly to the Polish standard PN-88/B-04481. In the investigation of the fine particles grain size distribution, the densimeter method with the Prószyński modification were used.

\section{RESULTS}

\section{Sediment samples analysis from the upper part of the reservoir}

From the comparison of the sieve curves for Samples 1 and 2 (Fig. 3) one can observe that in these samples exist visible difference between fine particle content. Sample 1 have a content of $10 \%$ particles smaller than $d_{10}=0.08 \mathrm{~mm}$ while in Sample 2 the grain size diameter $d_{10}=0.3 \mathrm{~mm}$ and is almost 4 times

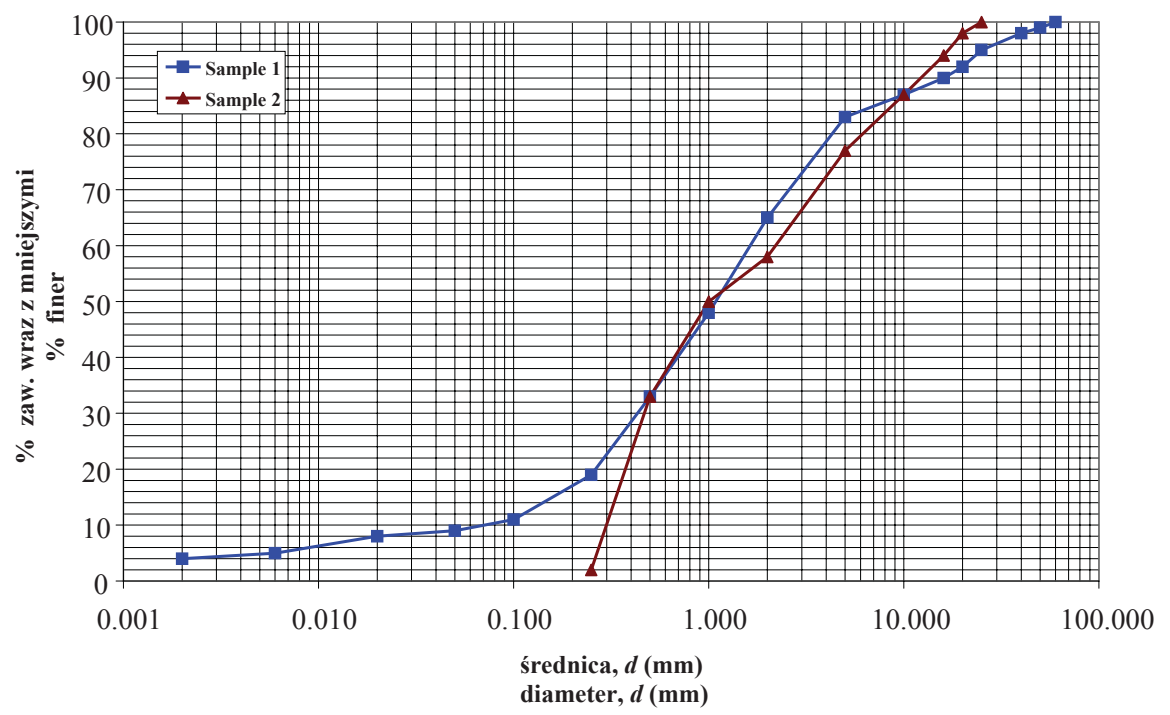

FIGURE 3. The grain size distribution for Otmuchów sediment Samples 1 and 2 
higher than in Sample 1. Also in Sample 2, does not occur fractions less than $0.25 \mathrm{~mm}$. From that comparison it can be stated that the existing vegetation favors sedimentation of small particles in estuary zone. For the coarser sediment fractions, the difference between content is smaller. The characteristic particle diameter $d_{50}$ is almost the same for both samples and amounts for Sample $1 d_{50}=1.1 \mathrm{~mm}$ and for Sample 2 $d_{50}=1.0 \mathrm{~mm}$. In the coarser fractions distribution it can be observed, that in estuary zone, also the coarser fractions are embedded. From Sample 1 all particles greater than diameter of $25 \mathrm{~mm}$ were embedded, in Sample 2 of these fractions have not been registrated. The comparison of the grain size distribution curves for Samples 1 and 3 (Fig. 4) and for Samples 2 and 3 (Fig. 5), showed that
Sample 3 contains much coarser material than Samples 1 and 2. In Sample 3, taken from the Nysa Kłodzka riverbed, does not exist fractions with diameter smaller than $0.5 \mathrm{~mm}$. One can observe that the all fractions with diameters smaller than $0.5 \mathrm{~mm}$ have been washed out from the sediments embedded (Sample 3) in riverbed and were transported to the reservoir Otmuchów. The characteristic sediment diameter $d_{50}=19 \mathrm{~mm}$ is almost 19 times higher than characteristic diameters $d_{50}$ for Samples 1 and 2 (Table 1). For the comparison characteristic diameter $d_{10}=1.2 \mathrm{~mm}$ is 4 times higher then $d_{10}=0.3 \mathrm{~mm}$ for Sample 2 and 15 times higher than $d_{10}=0.08 \mathrm{~mm}$ for Sample 1 . On the base of these results the grain size distribution in the longitudinal reservoir Otmuchów was determined (Table 2).

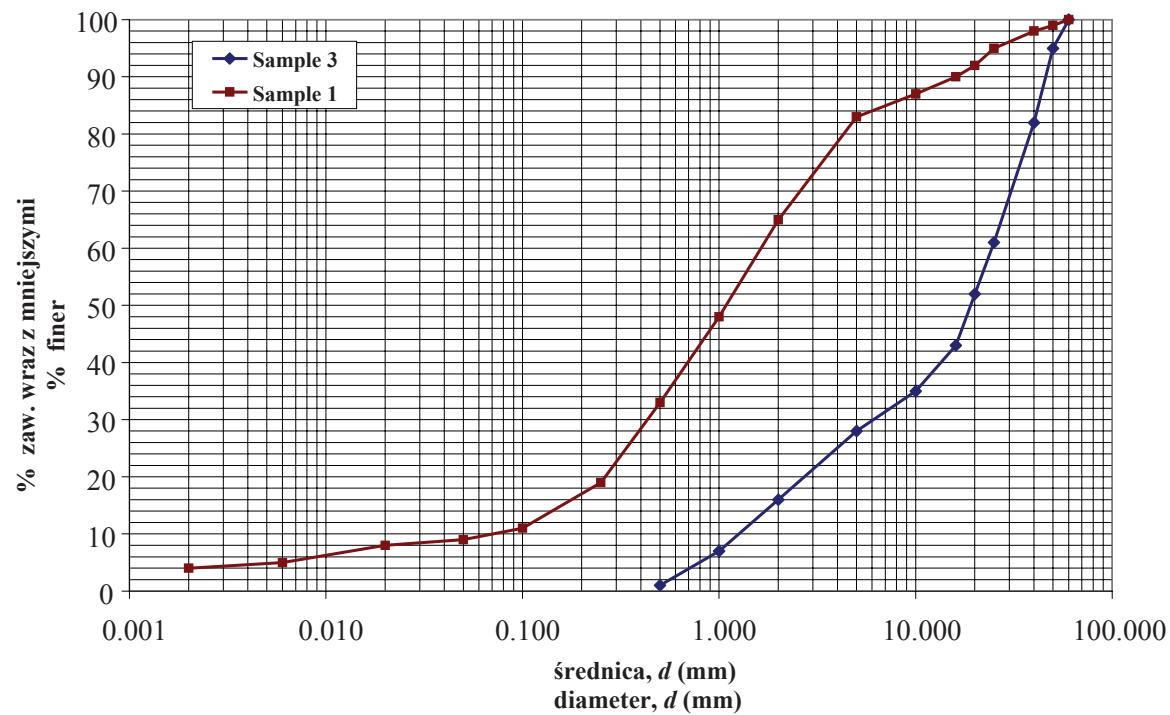

FIGURE 4. The grain size distribution for Otmuchów sediment Samples 1 and 3 


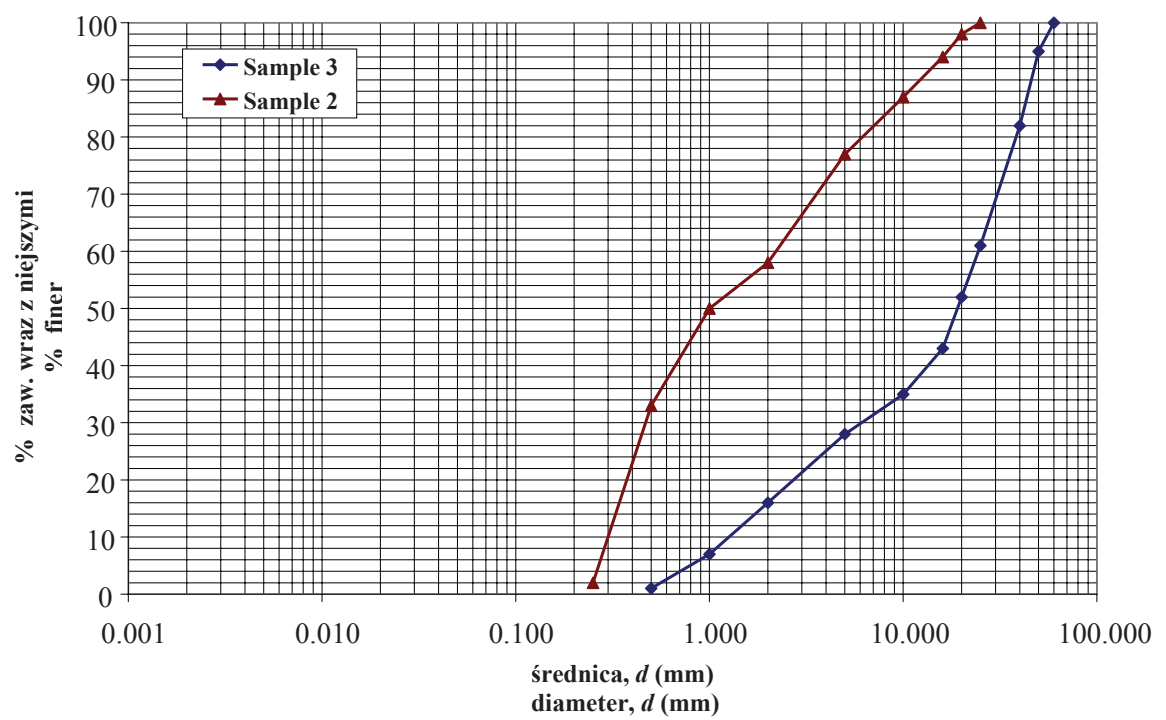

FIGURE 5. The grain size distribution for Otmuchów sediment Samples 2 and 3

TABLE 1. Characteristic sediment grain diameters

\begin{tabular}{|c|c|c|c|c|}
\hline $\begin{array}{c}\text { Sam- } \\
\text { ple }\end{array}$ & $\begin{array}{c}d_{10} \\
(\mathrm{~mm})\end{array}$ & $\begin{array}{c}d_{50} \\
(\mathrm{~mm})\end{array}$ & $\begin{array}{c}d_{60} \\
(\mathrm{~mm})\end{array}$ & $\begin{array}{c}d_{90} \\
(\mathrm{~mm})\end{array}$ \\
\hline 1 & 0.08 & 1.1 & 1.6 & 16.0 \\
\hline 2 & 0.3 & 1.0 & 2.1 & 12.0 \\
\hline 3 & 1.2 & 19.0 & 24.0 & 47.0 \\
\hline
\end{tabular}

TABLE 2. The sediment grain size distribution in longitudinal reservoir Otmuchów profile

\begin{tabular}{|c|c|}
\hline Distance from the dam $(\mathrm{m})$ & Diameter $-d(\mathrm{~mm})$ \\
\hline $300-400^{*}$ & 0.055 \\
\hline $900-1000^{*}$ & 0.088 \\
\hline $1900-2000^{*}$ & 0.083 \\
\hline $2000-3000^{*}$ & 0.030 \\
\hline$\sim 3900$ & $1.0\left(d_{10}=0.3\right)^{* *}$ \\
\hline$\sim 4800$ & $1.1\left(d_{10}=0.08\right)^{* *}$ \\
\hline
\end{tabular}

* Historical data presented after Głowski, Kasperek and Parzonka (2010).

** The authors present 2 diameter values $d_{50}$ and $d_{10}$ because in the historical data set there is no information what characteristic diameters were presented $d_{10}$ or $d_{50}$.
For the preliminary estimation of the sediment particles mobility of characteristic diameters $d_{50}$ and the movement parameters as critical shear stress and critical stream depth, the dimensionless Shields stress criterion have been used. The shields relation between the critical shear stress $-\tau_{k r}(\mathrm{~Pa})$ and the dimensionless mobility parameter $-\theta_{k r}$ is described with formula (1):

$$
\theta_{k r}=\frac{\tau_{k r}}{\left(\rho_{s}-\rho\right) \cdot g \cdot d_{50}}
$$

where:

$\theta_{k r}$ - Shields dimensionless mobility parameter (-),

$\tau_{k r}-$ critical shear stress $(\mathrm{Pa})$,

$\rho_{s}-$ sediment density $\left(\mathrm{kg} / \mathrm{m}^{3}\right)$,

$\rho$ - water density $\left(\mathrm{kg} / \mathrm{m}^{3}\right)$,

$\mathrm{g}-$ gravity acceleration $\left(\mathrm{m} / \mathrm{s}^{2}\right)$,

$d_{50}$ - sediment particle diameter $(\mathrm{m})$. 
The dimensionless mobility parameter $\left(\theta_{k r}\right)$ can be obtained from equations (2-6) formulated by Bonnefille and Yalin (Van Rijn 1993):

$$
\begin{array}{ll}
\theta_{k r}=0.24 D_{*}^{-1} & 1<D_{*} \leq 4 \\
\theta_{k r}=0.14 D_{*}^{-0.64} & 4<D_{*} \leq 10 \\
\theta_{k r}=0.04 D_{*}^{-0.1} & 10<D_{*} \leq 20 \\
\theta_{k r}=0.013 D_{*}^{0.29} & 20<D_{*} \leq 150 \\
\theta_{k r}=0.055 & D_{*}>150
\end{array}
$$

Parameter $\theta_{k r}$ is a function of dimensionless diameter $D_{*}$ obtained from formula (7):

$$
D_{*}=\left[(s-1) \mathrm{g} / v^{2}\right]^{1 / 3} \cdot d_{50}
$$

where:

$s-$ specific density $s=\frac{\rho_{s}}{\rho}(-)$, $v$ - kinematic fluid viscosity $\left(\mathrm{m}^{2} / \mathrm{s}\right)$.

The critical stream depth $\left(h_{k r}\right)$ causing sediment movement can be calculated from formula (8):

$$
h_{k r}=\frac{\tau_{k r}}{\gamma_{w} \cdot I}
$$

where:

$\gamma_{w}$ - water specific weight $\left(\mathrm{N} / \mathrm{m}^{3}\right)$,

$I$ - hydraulic gradient (-).

The mean annual water temperature values in Nysa Kłodzka changes in the range between $7.6-9.1^{\circ} \mathrm{C}$ (IMGW 2014). Kinetic viscosity for this temperature change respectively from 0.0000013862 to $0.0000013465 \mathrm{~m}^{2} / \mathrm{s}$. For the stream critical depth calculation the mean value of hydraulic gradient for Nysa Kłodzka equal $4.41 \%$ have been taken, because according to the authors, estimated for the $80-\mathrm{km}$ long upland Nysa Kłodzka sector, the hydraulic gradient equal $9.5 \%$ is not representative because presence of the 4 reservoirs cascade and temporary water damming. For a much more accurate analysis of the critical parameters of the sediment particles movement the real local hydraulic gradient should be designated in the future. Calculated after Shields criterion, critical shear stress values $\left(\tau_{k k}\right)$ and corresponding critical water depths $\left(h_{k r}\right)$ are presented in Tables 3 and 4.

TABLE 3. Critical shear stresses and water depths for the water temperature $t=7.6^{\circ} \mathrm{C}$ (kinematic viscosity $v=0.0000013862 \mathrm{~m}^{2} / \mathrm{s}$ )

\begin{tabular}{|c|c|c|c|c|c|}
\hline Sample & $d_{50}(\mathrm{~mm})$ & $D_{*}(-)$ & $\theta_{k r}(-)$ & $\tau_{k r}(\mathrm{~Pa})$ & $h_{k r}(\mathrm{~m})$ \\
\hline 1 & 1.1 & 20.27 & 0.0311 & 0.55 & 0.013 \\
\hline 2 & 1.0 & 18.43 & 0.0299 & 0.48 & 0.011 \\
\hline 3 & 19.0 & 350.08 & 0.055 & 16.91 & 0.39 \\
\hline
\end{tabular}

TABLE 4. Critical shear stresses and water depths for the water temperature $t=9.1^{\circ} \mathrm{C}$ (kinematic viscosity $v=0.0000013465 \mathrm{~m}^{2} / \mathrm{s}$ )

\begin{tabular}{|c|c|c|c|c|c|}
\hline Sample & $d_{50}(\mathrm{~mm})$ & $D_{*}(-)$ & $\theta_{k r}(-)$ & $\tau_{k r}(\mathrm{~Pa})$ & $h_{k r}(\mathrm{~m})$ \\
\hline 1 & 1.1 & 20.66 & 0.0313 & 0.56 & 0.013 \\
\hline 2 & 1.0 & 18.78 & 0.0298 & 0.48 & 0.011 \\
\hline 3 & 19.0 & 356.86 & 0.055 & 16.91 & 0.39 \\
\hline
\end{tabular}


On the base of these results (Tables 3 and 4) it can be stated, that characteristic particle diameters $d_{50}$ for Samples 1 and 2 have rather low critical shear stress values, respectively $\tau_{k r}=0.55 \mathrm{~Pa}$ and $\tau_{k r}=0.48 \mathrm{~Pa}$ in comparison with the value obtained for the much more greater representative particle diameter $d_{50}$ for Sample $3 \tau_{k r}=16.91 \mathrm{~Pa}$. This same relationship applies the values of the critical water depths causing particle movement. Small fractions with the diameters below $1.1 \mathrm{~mm}$ will be transported even at the stream with critical depths equal $h_{k r}=0.013 \mathrm{~m}$. These transport conditions occurs practically during all discharges in Nysa Kłodzka, the coarser material can be transported for the discharges where the water depth is greater than critical depth equal $0.39 \mathrm{~m}$. These difference in the critical erosion and sediment transport parameters causes that transport of the fine particles have continuous character and decide that in the estuary zone (flood capacity reserve) and in usable capacity of the reservoir Otmuchów these fine particles are embeded. The transport of the coarser material have temporary nature and may occurs during floods. After performed calculations it can be also stated, that the critical erosion and transport parameters for the analyzed particles diameters for the water temperatures 7.6 and $9.1^{\circ} \mathrm{C}$ obtain the same values and are independent of the water kinetic viscosity.

\section{CONCLUSIONS}

1. The satellite photo analysis confirm the silting of the upper part of reservoir Otmuchów on Nysa Kłodzka river. Embedded sediments are covered with the vegetation which intensify the fine particles sedimentation.

2. The authors completed the historic data set about sediment grain size distribution in the longitudinal reservoir Otmuchów profile on the base of the sediment samples analysis. They identified that in the estuary zone of Nysa Kłodzka river (flood capacity reserve) the fine particles with the representative diameters $d_{50}=1.1 \mathrm{~mm}$ or $d_{10}=0.08 \mathrm{~mm}$ have been embedded. In the usable capacity zone, the particles with the characteristic diameter $d_{50}=1.0 \mathrm{~mm}$ or $d_{10}=0.3 \mathrm{~mm}$ have been trapped.

3. On the base of comparison of the grain size distribution for all 3 samples and its critical mobility parameters it can be stated, that all settled in reservoir fractions with the diameters $d<1.1 \mathrm{~mm}$ have been washed out from the sediments transported by Nysa Kłodzka and its transportation regime have continuous character. The transport of the coarser material have temporary nature and may occurs during floods.

4. After performed calculations it can be also stated, that the critical erosion and transport parameters for the analyzed particles diameters for the 
water temperature range $7.6-9.1^{\circ} \mathrm{C}$ obtain the same values and are independent of the water kinetic viscosity.

\section{REFERENCES}

BĄK Ł., DĄBKOWSKI Sz.L. 2013: Spatial distribution of sediments in Suchedniów reservoir. Journal of Water and Land Development 19 (7-12), 13-22.

CIGB ICOLD 2009: Sedimentation and sustainable use of reservoir and river systems. Draft ICOLD Bulletin. Sedimentation Committee.

Department of the Environment Transport and the Regions (DETR) 2001: Sedimentation in Storage Reservoirs Final Report, Halcrow Water.

De ANDRADE CUNHA D., VALLE FERREIRA L. 2012: Impacts of the Belo Monte Hydroelectric Dam construction on pioneer vegetation formations along the Xingu river, Para State. Brazil, Brazilian Journal of Botany 35 (2), 119-127.

DYSARZ T., WICHER-DYSARZ J. 2006: Assessment of hydrologic regime changes induced by the Jeziorsko dam performance and morphodynamic processes in the Warta river. Annals of Warsaw Agricultural University - SGGW, Land Reclamation 37, 43-54.

DYSARZ T., WICHER-DYSARZ J., SOJKA M. 2014: Two approaches to forecasting of sedimentation in the Stare Miasto Reservoir, Poland. In: Reservoir Sedimentation. A.J. Schleiss et al. (Eds). Taylor \& Francis Group, London, 119-127.

ELLIOTT A.H. 2000: Settling of fine sediment in a channel with emergent vegetation. Journal of Hydraulic Engineering 126 (8), 570-577.

GŁOWSKI R., PARZONKA W. 2007: Exploitation and influence of storage reservoir in Brzeg Dolny on Odra River valley. Nauka Przyroda Technologie 1, 2, 1-12 [in Polish].

GŁOWSKI R., KASPEREK R., PARZONKA W. 2010: The preliminary analysis of silting conditions of the storage reservoir Otmuchów localised in upland region, No: 8/2/2010. Polish Academy of Science, Krakow Branch, Infrastructure and Ecology of Rural Areas, 27-36 [in Polish].
GRAF W.H. 1984: Hydraulics of reservoir sedimentation. Ecole polytechnique federale de Lausanne. Communication du Laboratoire d'Hydraulique 51.

GÓRSKI D. 2009: Sediment transport reduction in constructed wetlands. Przeglad Naukowy Inżynieria i Ksztaltowanie Środowiska 18, 2 (44), 30-37 [in Polish].

IMGW 2010: Preventing the degradation of Polish reservoirs, Przeciwdziałanie degradacji polskich zbiorników retencyjnych. The synthesis report of the work done in 2009. (Stages I-III) [in Polish].

IMGW 2014: Hydrological Yearbook of Surface Water. Warszawa.

KOTUSZ J., KUSZNIERZ J., POPIOŁEK M., WITKOWSKI A. 2009: Ichthyofauna of the Nysa Kłodzka River system. Roczniki Naukowe PZW (Scientific Annual of the Polish Angling Association) 22, 5-58 [in Polish].

MICHALEC B., PECCZEK K., STRUTYŃSKI M. 2009: Spatial distribution of bottom sediment deposits in water reservoirs at Zasławice. Annals of Warsaw Agricultural University - SGGW, Land Reclamation 41, 49-56.

MORRIS G.L., FAN J. 1998: Reservoir sedimentation handbook, Design and management of dams, reservoirs, and watersheds for sustainable use. McGraw-Hill Companies Inc., USA.

PIKUL K., MOKWA M. 2008: Influence of predams on the main reservoir silting process. Przeglad Naukowy Inżynieria i Kształtowanie Środowiska 17, 2 (40), 185-193 [in Polish].

PN-88/B-0448. Grunty budowlane. Badanie próbek gruntu.

PRZEDWOJSKI B. 1998: The morphology of rivers and river forecasting processes. Wydawnictwo Akademii Rolniczej im. Augusta Cieszkowskiego w Poznaniu [in Polish].

Van RIJN L.C. 1993: Principles of sediment transport in rivers, estuaries and costal seas. Aqua-publications - I11, Amsterdam.

WICHER-DYSARZ J., DYSARZ T. 2015: Uncertainty in assessment of annual inflow of sediments to the Stare Miasto reservoir based on empirical formulae. Acta Scientiarum Polonorum Formatio Circumiectus 14 (1), 4-16 [in Polish]. 
Streszczenie: Segregacja ziarnowa rumowiska osadzanego w obrębie czaszy zbiornika wodnego Otmuchów. Zbiornik Otmuchów położony jest na rzece Nysie Kłodzkiej i stanowi pierwszy element kaskady zbiorników Nysa - Otmuchów. Ze względu na położenie w obrębie jego czaszy osadzana jest znaczna ilość rumowiska transportowanego przez Nysę Kłodzką. Po powodzi w 1997 roku na zbiorniku Otmuchów dla zwiększenia jego rezerwy powodziowej wprowadzono dwa poziomy piętrzenia - letni i zimowy. Utrzymywanie przyjętego, letniego poziomu piętrzenia powoduje, że przez znaczną część roku zbiornik Otmuchów pracuje w warunkach obniżonego zwierciadła wody. Skutkiem tego jest postępujący proces zamulania ujściowej części zbiornika, widoczny na zdjęciach satelitarnych. Dodatkowo w strefie ujściowej, na osadzonym rumowisku rozwija się roślinność pionierska stabilizująca osady i intensyfikująca w strefie ujściowej Nysy Kłodzkiej zatrzymywanie transportowanego rumowiska. Proces ten przyczynia się do stopniowej utraty części pojemności. W artykule przedstawiono wyniki badań składu prób rumowiska pobranych w strefie pojemności użytkowej zbiornika i strefy ujściowej Nysy Kłodzkiej położonej w rejonie rezerwy powodziowej. Przeprowadzone badania pozwoliły na uzupełnienie danych historycznych o rozkładzie rumowiska osadzanego w profilu podłużnym zbiornika Otmuchów. Uzyskane wyniki badań pozwoliły na uzupełnienie historycznego obrazu rozkładu uziarnienia rumowiska osadzanego w profilu zbiornika Otmuchów oraz ocenę parametrów mobilności (erozji) rumowiska o ustalonych średnicach.

\section{MS received January 2017}

\section{Authors' address:}

Robert Głowski, Robert Kasperek Instytut Inżynierii Środowiska Wydział Inżynierii Kształtowania Środowiska i Geodezji

Uniwersytet Przyrodniczy we Wrocławiu pl. Grunwaldzki 24, 50-363 Wrocław Poland e-mail: robert.glowski@upwr.edu.pl 